\title{
Impact of Human Activities on Nutrient and Trophic Status of some Selected Lagoons in Ghana
}

\author{
O. D. Ansa-Asare ${ }^{*}$, E. Mensah ${ }^{2}$, M. Entsua-Mensah ${ }^{1}$, C. A. Biney ${ }^{1}$ \\ ${ }^{1}$ CSIR-Water Research Institute, P. O. Box AH 38, Achimota, Ghana \\ ${ }^{2}$ Kwame Nkrumah University of Science and Technology, Department of Agricultural \\ Engineering, Kumasi, Ghana \\ *Corresponding author.
}

\begin{abstract}
The nutrient and trophic status were used to assess the impact of human activities on lagoon by determining the trophic status of the lagoons and then using nutrient parameters and transparency in a form of model to predict the trophic status index (TSI) of the lagoon waters. The trophic index of Benya, Nakwa, Amisa and Nyanya ranges between 35.039.0 and falls within Carlson's TSI range scale of 30-40, which implies that their waters are oligotrophic. The Oyibi lagoon is mildly eutrophic (Carlson's TSI scale of 56) in the riverine portion. However, at the seaward end it has TSI of 42, which is moderately clear. Similarly, Muni lagoon is moderately clear with TSI range of 35.8-43.1. The Sakumo II lagoon is hypereutrophic at the riverine end (Carlson's TSI of 87.8). The seaward end is oligotrophic. The high phosphorus (231.9 kg/day) and nitrogen $(927.9 \mathrm{~kg} /$ day) recorded at Nyanya lagoon are as a result of domestic activities mainly from the wastes generated from humans at the lagoon and its surroundings. The use of nutrients and transparency, in predicting the trophic status of lagoons and coastal waters is a new and emerging scientific way of looking at lagoon trophic status. The nutrient inputs into lagoons, as well as transparency, are direct impacts of human activities. The model has proved to be useful in explaining the impact of human activities on the trophic status of lagoons in Ghana. The model was assessed by predicting the observed versus predicted, and this showed a performance index $\left(\mathrm{R}^{2}\right)$ of $95.1 \%$. This shows that the model is able to use various nutrient and transparency values to predict the trophic status of lagoons. The model is able to predict lower or oligotrophic TSI values better than higher or hypereutrophic values. The model has then been used successfully to predict various TSI values from the lagoons.
\end{abstract}

\section{Introduction}

There are two types of lagoons fringing the West African coast. The coastal lagoons of Ghana have been categorised into 'open' and 'closed' by Boughey (1957). The open lagoon, often referred to as an estuary, has sufficient volume of water at all seasons to maintain a permanent outflow from its mouth into the sea. In Ghana, such lagoons occur more in the western part of the coastline where rainfall is heavy (mean of about $1250 \mathrm{~mm}$ per annum) and the lagoons are fed continuously by rivers. The closed lagoons are fed by seasonal rivers and streams. They usually lie behind a sand barrier, which separates them from the sea and are normally opened for one or two months of the year during the rainy season (May-September). Most of these lagoons are located on the eastern coastal region where the rainfall is low. Associated with all lagoons in tropical areas are coastal wetland mangrove swamps.

Lagoons have been found to be extremely vulnerable to build up of contaminants from the terrestrial, freshwater and marine environment. Because lagoons are rich in nutrient salt and an elementary productivity force resource, they have become an area for developing sea transport, reclamation, aquaculture and tourism (Zhuang, 1992). Therefore, there are more human activities in lagoonal coast than in the other kinds of coasts.

There have been increases in deposition of sediments in lagoons as a result of land use changes, overgrazing and urbanization. Sewage discharges are also causing eutrophication, increasing the frequency of toxic algal blooms and creating health hazards. Lagoons in Ghana have a great influence on the socio-economic well-being and health of communities that live close to and beyond them.

The existing balance between the input of inorganic nutrients from different sources and their use or transport through assimilation, sedimentation or export from the system is important in evaluating coastal trophic state of lagoons. All trophic classifications are based on arbitrary 
divisions of a continuum, and, in marine ecosystems, no specific criteria have yet been established as it is the case in freshwater ecosystems (Havens et al., 1999).

The eight lagoons (Korle, Benya, Muni, Nakwa, Nyanya, Oyibi, Sakumo II and Amisa), which were studied, are associated with very intensive land use and waste disposal. There is also intensive harvesting of mangrove trees in some of the lagoons. The lagoons serve as conduits for the transport of both solid and liquid waste from most parts of the cities into the sea.

Almost all the lagoons are used in artisanal fisheries; they play an important role in the economy of some coastal inhabitants, especially during the off-season for marine fishing (EntsuaMensah et al., 2004). There is growing evidence of disquieting determination of these lagoons under stress from human-induced interference. There is, therefore, a need for the adoption of effective conservation measures, as well as a search for wiser and sustainable management of the resources of the lagoons.

The specific objectives of this paper are to: (1) determine various sources of nutrient contaminants and their impact on the lagoon waters, (2) assess the trophic status of the lagoons, and (3) assess the loading rate of contaminants (nutrients) on the lagoons.

Study area

\section{Materials and methods}

The eight lagoons (Korle, Benya, Muni, Nakwa, Nyanya, Oyibi, Sakumo II and Amisa) lie within longitudes $1^{\circ} 30^{\prime} \mathrm{W}$ and $0^{\circ} 30^{\prime} \mathrm{E}$, and latitudes $5^{\circ} \mathrm{N}$ and $5^{\circ} 50^{\prime} \mathrm{N}$. The geology of the coastal plains of Ghana has been divided into three main sections by Dickson \& Benneh (1980). The south-east coastal plain is up to $80 \mathrm{~km}$ wide and the land is flat with a general elevation of less than $75 \mathrm{~m}$. Between Accra and Songor lagoon the coast is sometimes cliffed and is composed of mid Devonian sandstone, grits shales. Further eastwards of the coast line is fairly smooth and is characterised by sandbars. It includes the Volta delta and the Keta lagoon. This portion of the coast is made up of recent unconsolidated sand clay and gravel. The central plain is composed of red continental deposits, limonitic sand, sandy clay and gravel. The eight lagoons fall within these set.

The whole coastal plain has two rainy seasons, the principal one reaching its maximum in May-June and the minor season begins in mid-August and ends in October. The mean annual rainfall is about $735 \mathrm{~mm}$. The main economic activities in the catchment of the lagoons are fishing and salt winning. The geographical locations of the lagoons with their uses and other activities have been listed in Table 1 .

TABLE 1

Locations of lagoons with uses and activities

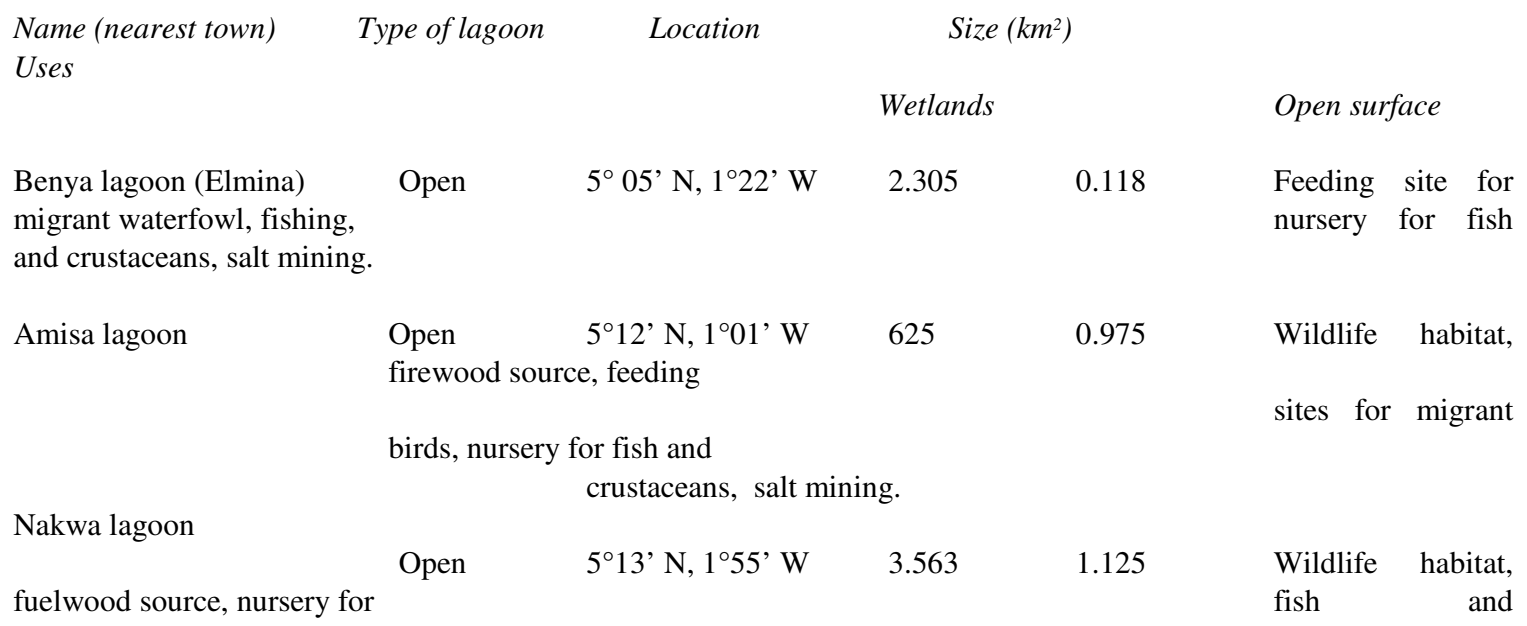

West African Journal of Applied Ecology, Vol. 12, 2008 
crustaceans, feeding site for migrant

birds, salt

extraction.

Nyanya lagoon

(Gomoa- Nyanyano)

feeding site for migrant

Open

Marginal

0.245

extraction.

Sakumo II lagoon

site for migrant birds, nurser

Op

and crustaceans.

Oyibi lagoon

site for migrant birds, nursery

$$
\text { Op }
$$

and crustaceans, farming, salt

Muni lagoon
site for migrant birds, nursery

Cl

Closed

$5^{\circ} 19^{\prime} \mathrm{N}, 0^{\circ} 39^{\prime} \mathrm{E}$

$-$

5.813

1.063

and crustaceans, farming, fuel

Korle lagoon

Open

$5^{\circ} 38^{\prime} \mathrm{N}, 0^{\circ} 02^{\prime} \mathrm{W}$

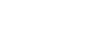

$5^{\circ} 21^{\prime} \mathrm{N}, 1^{\circ} 36^{\prime} \mathrm{E}$

0.026

fuelwood source.

Source: FOE, 1994.

\section{Water samples}

Two water samples were taken from each of the eight lagoons from the seaward end (sampling point 2) and the other from the riverine portion (sampling point 1). The sampling programme was undertaken monthly from July 2001 to June 2002. In the field, all the samples were stored in opaque plastic bottles in an ice-chest at $4{ }^{\circ} \mathrm{C}$ and analysed within 5 days.

Temperature and $p \mathrm{H}$ were determined in situ, using a mercury-in-glass thermo-meter, and a portable $p \mathrm{H}$ meter, respectively. For chlorophyll "a" (CHl-a) and Secchi disc determinations, samples were taken using standardised methods (APHA, 1998). All other parameters and nutrients $\left(\mathrm{PO}_{4}-\mathrm{P}, \mathrm{NO}_{3}-\mathrm{N}, \mathrm{NH}_{4}-\mathrm{N}\right)$ were also analysed using APHA (1998). Korle lagoon was heavily polluted to the extent that chlorophyll "a" could not be determined. The nutrients were analysed within 1.0-1.9\% relative standard deviation using colorimetric methods.

The trophic status was estimated using the Carlson Index based on CHl-a concentration (Equation 1), as the presence of chlorophyll "a" in the water column is considered an almost immediate response to nutrient variability (Carlson, 1977). This allows monitoring and quantification data to be used as trustworthy indicators of phytoplankton biomass variations and ecosystem trophic state:

$T S I(C H l-a)=10 \quad \frac{6-2.04-0.68 \ln C H l-a}{\ln 2} \quad \cdots . . .(1)$

TSI = Trophic state index

TSI ranges along a scale from 0-100 that is based upon relationships between Secchi disc and surface water concentrations of algal chlorophyll and phosphorus. An increase in TSI of 10 units corresponds to halving of Secchi disc and doubling of phosphorus concentration.

\section{Determination of nutrient inputs from settlements around the lagoons}

The inputs by the major settlements along the lagoon catchments were calculated to determine their significance. The WHO rapid assessment for polluted waters (Suess, 1982) was used for computations. Based on population estimates supplied by the Statistical Service, Ghana (2000), the loads per capita per day were used to compute projected nutrient inputs from settlements to the lagoons. 
The scale and hierarchization produced from the Carlson indices, specifically for this study are:

TSI (Carlson, $\quad$ Trophic status index and water quality

1977)

$<30 \quad$ Oligotrophic; clear water, highDO throughout the year in the entire hypolimnion

30-40 Oligotrophic; clear water; possible periods of limited hypolimnetic anoxia =0)

40-50 Moderately clear water; increasing change of hypolimnetic anoxia, fully supportive of all swimmable/aesthetic uses

50-60 Mildly eutrophic; decreased transparency; anoxic hypolimnion; macrophytic problems; warm-water

fisheries only; supportive of all swimmable/aesthetic uses but "threatened".

60-70 Blue-green algae dominance; scums possible; extensive macrophyte problems

70-80 Heavy algal blooms possible throughout summer; dense macrophyte blooms; hypereutrophic

$>80 \quad$ Algal scums; fish kills; few macrophytes due to algal shading; fish dominance; hypereutrophic

\section{Nutrients inputs from settlements around the lagoons}

\section{Results and discussion}

It is evident that the people from Nyanyano contributed the greatest nutrients to the lagoon waters. An observation made at the site with regard to indiscriminate defaecation also confirms this fact. The high phosphorus (231.9 kg/day) and nitrogen $(927.9 \mathrm{~kg} /$ day $)$ recorded in Nyanya lagoon are as a result of domestic activities, mainly from the wastes generated from humans into the lagoon and its surroundings (Table 2).

TABLE 2

Nutrient inputs from settlements

Catchment population (2004)
22861
6347
4629
20100
23249
77334
23852
30144

Settlement
Benya
Nakwa
Amisa (Asaafa)
Oyibi
Muni
Nyanyano
Sakumo II
Korle

Total N (kg/day)

274.1

76.2

55.5

241.2

278.9

927.9

286.2

361.7
Total P (kg/day)

68.6

19.1

13.9

60.3

69.7

231.9

71.5

90.4

The coastal environment and ecosystem are easily disturbed because of unrestrained human activities and inadequately planned land use system; consequently, the economic value of this resource is negatively affected. At present, because of salt winning in the lagoon environment, the feeding site for migrant birds has been reduced. If this situation continues, tourism will be badly affected (Table 2) (FoE, 1994).

\section{Nutrients and trophic status index in eight selected lagoons in Ghana}

Trophic status index of the lagoons. The trophic index of Benya, Nakwa, Amisa and Nyanya ranges between 35.0-39.0 and falls within Carlson's TSI range scale of 30-40, which implies that their waters are oligotrophic. However, there are limited hypolimnetic periods within the year, and these are caused by the presence of nutrients through human activities. The Oyibi lagoon was mildly eutrophic (Carlson's TSI scale of 56) in the riverine portion, because of agricultural and other domestic activities. However, due to dilution and mixing at the seaward end, which was moderately clear, it had TSI of 42. Similarly, Muni lagoon was moderately clear with TSI range of 35.8-43.1 (Table 3). The Sakumo II lagoon is hypereutrophic at the riverine end (Carlson's TSI of 87.8). The seaward end was oligotrophic because of the dilution and mixing of seawater. 
Almost all the trophic status indices described in this text and also by the lagoons could be true reflections of the reality on the field.

TABLE 3

Nutrients and trophic status index of the eight lagoons in Ghana

\begin{tabular}{|c|c|c|c|c|c|c|c|}
\hline Stations & Sampling points & $\begin{array}{l}\text { Chl-a } \\
(m g / l)\end{array}$ & Transparency & $\begin{array}{r}\mathrm{NO}_{3}-\mathrm{N} \\
(\mathrm{mg} / \mathrm{l})\end{array}$ & $\begin{array}{r}\mathrm{PO}_{4}-\mathrm{P} \\
(m g / l)\end{array}$ & $\begin{array}{r}\mathrm{NH}_{4}-\mathrm{N} \\
(\mathrm{mg} / \mathrm{l})\end{array}$ & $\begin{array}{l}\text { TSI } \\
(C h l-a)\end{array}$ \\
\hline \multirow[t]{2}{*}{ Benya } & 1 & 2.31 & 38.8 & 1.19 & 0.184 & 8.13 & 38.8 \\
\hline & 2 & 1.57 & 35.1 & 0.770 & 0.239 & 4.39 & 35.0 \\
\hline \multirow[t]{2}{*}{ Nakwa } & 1 & 2.36 & 6.12 & 0.463 & 0.377 & 4.69 & 39.0 \\
\hline & 2 & 1.97 & 6.77 & 0.374 & 0.404 & 4.12 & 37.2 \\
\hline \multirow[t]{2}{*}{ Amisa } & 1 & 2.23 & 6.47 & 0.876 & 0.074 & 3.02 & 38.4 \\
\hline & 2 & 2.31 & 6.07 & 0.395 & 0.106 & 3.26 & 38.8 \\
\hline \multirow[t]{2}{*}{ Oyibi } & 1 & 14.2 & 15.7 & 7.48 & 0.465 & 2.63 & 56.5 \\
\hline & 2 & 3.33 & 11.6 & 1.29 & 0.201 & 1.69 & 42.4 \\
\hline \multirow[t]{2}{*}{ Muni } & 1 & 3.60 & 7.64 & 0.424 & 0.558 & 3.95 & 43.1 \\
\hline & 2 & 1.70 & 6.41 & 0.379 & 0.459 & 3.87 & 35.8 \\
\hline \multirow[t]{2}{*}{ Nyanya } & 1 & 1.96 & 9.85 & 0.595 & 0.202 & 4.29 & 37.1 \\
\hline & 2 & 1.96 & 13.1 & 0.483 & 0.182 & 3.81 & 37.2 \\
\hline \multirow[t]{2}{*}{ Sakumo II } & 1 & 340 & 264 & 28.6 & 2.18 & 5.95 & 87.8 \\
\hline & 2 & 2.39 & 41.1 & 10.9 & 2.03 & 5.96 & 39.1 \\
\hline \multirow[t]{2}{*}{ Korle } & 1 & - & 2.69 & 23.3 & 7.95 & 115 & - \\
\hline & 2 & - & 3.41 & 6.82 & 8.13 & 120 & - \\
\hline
\end{tabular}

$N B$ ' - ' means no reading was taken, because it was not detectable.

Ammonia-nitrogen $\left(\mathrm{NH}_{4}-\mathrm{N}\right)$. Ammonia-N mean annual concentrations ranged from $2.63 \mathrm{mg} / \mathrm{l}$ in Oyibi lagoon to $115.0 \mathrm{mg} / \mathrm{l}$ in Korle for sampling point 1, which was the riverine portions of the lagoons (Table 3). The seaward end recorded a range of $1.69 \mathrm{mg} / \mathrm{l}$ in Oyibi to $120.0 \mathrm{mg} / \mathrm{l}$ in Korle lagoon. Generally, the mean annual concentration of ammonia-N for all the lagoons for the riverine portion $(18.5 \mathrm{mg} / \mathrm{l})$ was slightly higher compared to the mean annual seaward portion $(18.4 \mathrm{mg} / \mathrm{l})$.

Ammonia-N has an important role as key plant nutrient, as it is the most favourable form of plant $\mathrm{N}$ for assimilation (Wetzel, 2001). Large amounts of ammonia-N are derived mostly from organic sources by degradation of nitrogenous organic matter and are taken up at a higher rate in the day than in the night (Birch et al., 1981). The high mean annual ammonia-N concentra-tions of all the lagoons were a reflection of the highly localised inputs of contaminated organic waste in sewage effluents from the nearby towns, especially Korle lagoon (Asante et al., 2003). The remaining lagoons with the exception of Sakumo I, agricultural run-off in the catchment area, are also the causes of the high levels of ammonia-N. Ammonia-N is known to be the major fraction of total nitrogen in domestic effluent (Maybeck et al., 1990).

Nitrate-nitrogen. The results in Table 3 show that nitrate-nitrogen concentrations for all the lagoons were higher in the riverine end (1) than at point 2, Nakwa, and this is an indication of the contribution of nutrient from rivers into lagoons. Sakumo II lagoon showed extremely high levels $(28.6 \mathrm{mg} / \mathrm{l})$ of nitrate-nitrogen at the riverine end. This indicates high loading from the river into the lagoon. High nitrate nitrogen is an indication of the impact of human and domestic activities in the lagoon catchment area.

The results in Table 3 also show that the nitrate-nitrogen concentrations are from both point and non-point sources, and are mainly from the rivers into the lagoons. The lagoons themselves 
were dominated by non-point sources from nearby agricultural runoff and domestic activities. There is a very strong correlation between TSI and nitrate-nitrogen with correlation coefficient of $0.9234(P<0.05)$. This is an indication of the contribution of nitrate-nitrogen to the trophic status and also the algal biomass content of the lagoons.

Phosphonsphosphate $\left(\mathrm{PO}_{4} P\right)$. Generally, for phosphate-phosphorus $\left(\mathrm{PO}_{4}-\mathrm{P}\right)$ concen-trations from Oyibi, Muni, Nyanya and Sakumo II, the riverine portions had higher concentrations than the seaward end, suggesting that most of the $\mathrm{PO}_{4}-\mathrm{P}$ came from the river into the lagoon (Table 3). Table 4 shows that the phosphate-phosphorus concentrations are mainly from non-point sources with varied sources from both the sea and the river. The levels of $\mathrm{PO}_{4}-\mathrm{P}$ concentrations between the rivers and the lagoons are indicative of the impact of domestic and agricultural activities from the various lagoons. The dry season $\mathrm{PO}_{4}-\mathrm{P}$ values were lower than those of the rainy season, with higher coefficient of variation. The trend was observed in all the nutrients in the lagoons. This was due to the rains and its resultant runoff.

TABLE 4

Seasonal variation of nutrients in the lagoons

\begin{tabular}{|c|c|c|c|c|c|c|c|}
\hline Season & Sampling points & $\begin{array}{l}\mathrm{NO}_{3}-\mathrm{N} \\
(\mathrm{mg} / \mathrm{l})\end{array}$ & $C V(\%)$ & $\begin{array}{l}\mathrm{PO}_{4}-\mathrm{P} \\
(\mathrm{mg} / \mathrm{l})\end{array}$ & $C V(\%)$ & $\begin{array}{c}\mathrm{NH}_{4}-\mathrm{N} \\
(\mathrm{mg} / \mathrm{l})\end{array}$ & $C V(\%)$ \\
\hline \multirow[t]{2}{*}{ Wet } & 1 & 8.17 & 135 & 2.17 & 171 & 29.2 & 208 \\
\hline & 2 & 2.24 & 94.3 & 2.15 & 187 & 29.6 & 213 \\
\hline \multirow[t]{2}{*}{ Dry } & 1 & 7.50 & 145 & 0.695 & 98.9 & 5.58 & 23.5 \\
\hline & 3.20 & 0.647 & 117 & 5.13 & & & \\
\hline
\end{tabular}

Using nutrients to predict trophic status index

Despite the fact that different approaches have been devised for evaluating the trophic status index (TSI), few have been found to be useful for comparison and generalization of their results. The existing balance between the input of inorganic nutrients from different sources and their use or transport through assimilation, sedimentation or export from the system is important in evaluating coastal trophic state.

The use of nutrients and transparency in predicting the trophic status of lagoons and coastal waters is new and emerging scientific way of looking at lagoon trophic status. The nutrient inputs into lagoons as well as transparency are direct impacts of human activities. In this paper, ammonia-nitrogen, nitrate-nitrogen, phosphate-phosphorus and transparency were used in a regression relationship to predict the trophic status of the lagoons in Ghana. The prediction was good, with a coefficient of determination $\left(\mathrm{R}^{2}\right)$ of $94.5 \%$. The following regression expression was obtained for the variables:

$\mathrm{TSI}_{\text {Lagoons }}=42.9-0.791 \mathrm{NH}_{4}-\mathrm{N}+2.42 \mathrm{NO}_{3}-\mathrm{N}-11.2 \mathrm{PO}_{4}-\mathrm{P}+0.014$ Trans

The TSI is the trophic status index of the lagoons studied (Table 5), $\mathrm{NH}_{4}-\mathrm{N}$ is the ammonianitrogen of the lagoons $(\mathrm{mg} / \mathrm{l}), \mathrm{NO}_{3}-\mathrm{N}$ is the nitrate-nitrogen of the lagoon $(\mathrm{mg} / \mathrm{l})$ and $\mathrm{PO}_{4}-\mathrm{P}$ is phosphorus in phosphate $(\mathrm{mg} / \mathrm{l})$. Trans. $=$ Transparency $(\mathrm{cm})$.

TABLE 5

Estimated mean trophic status index of some lagoons in Ghana

$\begin{array}{cccc} & & \text { Observed } & \text { Predicted } \\ \text { Stations } & \text { Sampling } & \text { TSI } & \text { TSI }\end{array}$

West African Journal of Applied Ecology, Vol. 12, 2008 


\begin{tabular}{llcr} 
& points & \\
Benya & 1 & 38.8 & 37.9 \\
& 2 & 35.0 & 39.1 \\
Nakwa & 1 & 39.0 & 36.2 \\
& 2 & 37.2 & 36.2 \\
Amisa & 1 & 38.4 & 41.9 \\
& 2 & 38.8 & 40.2 \\
Oyibi & 1 & 56.5 & 54.0 \\
& 2 & 42.4 & 42.6 \\
Muni & 1 & 43.1 & 34.7 \\
& 2 & 35.8 & 35.7 \\
Nyanya & 1 & 37.1 & 38.8 \\
\multirow{2}{*}{ Sakumo II } & 2 & 37.2 & 39.2 \\
& 1 & 87.8 & 87.0 \\
Korle & 2 & 39.1 & 42.6 \\
& 1 & - & - \\
& 2 & - & -
\end{tabular}

$N B^{\prime}-$ ' means no reading was taken, because it was not detectable.

Model sensitivity of the individual parameters. Quantitative assessment of model behaviour was derived from the calibration results, using the numerical criterion (Equation 3) for minimising the sum of squares of the residuals $\left(\mathrm{E}_{\mathrm{r}}\right)$ for the TSI:

$$
E_{r}=\begin{array}{rc}
1 & \sum \mathrm{C}_{\mathrm{pi}}-\mathrm{C}_{\mathrm{mi}}{ }^{2} \\
\mathrm{n}-\mathrm{p} & \mathrm{i}-1
\end{array}
$$

where $\mathrm{n}$ is the number of experimental results (e.g.168 for data set in a one year period), with sampling every month for one year, $p$ is the number of estimated parameters ( $p=4$ in this case), $\mathrm{C}_{\mathrm{pi}}$ is the concentration of the TSI predicted by the model and $\mathrm{C}_{\mathrm{mi}}$ is experimental TSI concentration. It was found out that ammonium-nitrogen $\left(\mathrm{NH}_{4}-\mathrm{N}\right)$, nitrate-nitrogen $\left(\mathrm{NO}_{3}-\mathrm{N}\right)$, phosphorus-phosphate $\left(\mathrm{PO}_{4}-\mathrm{P}\right)$ and transparency (Trans.) were all sensitive parameters in the model, judging from their error curves (Fig. 2), which were narrow and well separated.

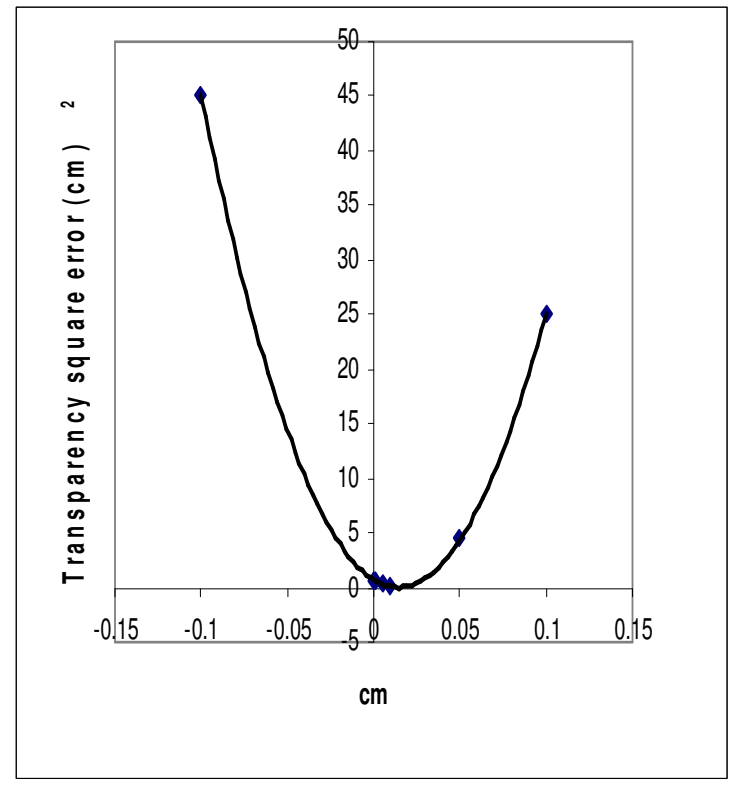

West African Journal of Applied Ecology, Vol. 12, 2008 


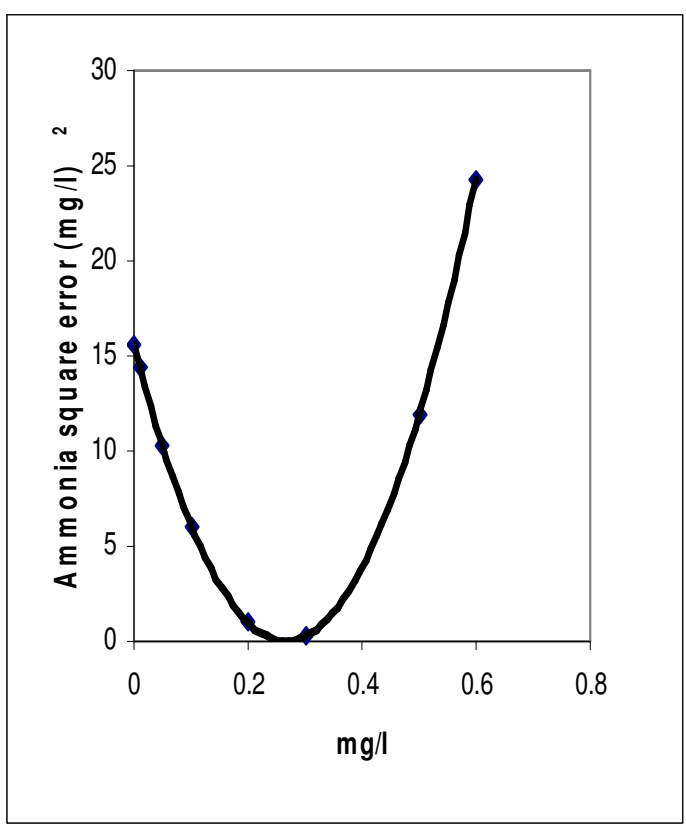

Ammonium-nitrogen, nitrate-nitrogen and phosphorus-phosphate were indicative of considerable human activity impact on the lagoon waters, and these were confirmed by their high levels found in the lagoon waters. Transparency was also sensitive to the model because of the linkage of productivity to TSI. Generally, the testing of the TSI model has confirmed that the total trophic index depends on phosphorus-phosphate, ammonium-nitrogen, nitrate-nitrogen and transparency as key parameters, all of which are included in the model.

Sensitivity analysis, according to France \& Thornley (1984), shows a narrow curve (Fig. 2) when the parameters in the model are sensitive. Fig. 2a-d show the various sensitivity plots for individual parameters in the model. The order of sensitivity follows this decreasing trend: $\mathrm{PO}_{4}-\mathrm{P}$ $>\mathrm{NH}_{4}-\mathrm{N}>$ Trans. $>\mathrm{NO}_{3}-\mathrm{N}$. The curves follow this order in terms of its sensitivity ('narrowness').

From these diagrams, one can infer that $\mathrm{PO}_{4}-\mathrm{P}, \mathrm{NH}_{4}-\mathrm{N}$, Trans. and $\mathrm{NO}_{3}-\mathrm{N}$ are all location dependent, and the degree of sensitivity depends on the concentration level. It is, therefore, not surprising that $\mathrm{PO}_{4}-\mathrm{P}$ is the most sensitive parameter in determining the trophic status of the lagoon, because phosphorus-phosphate is known to be the limiting nutrient for photosynthesis. The model confirms this idea, and the sensitivity analysis is also confirming this idea that the model is more sensitive to this parameter in the lagoons of Ghana.

Assessment of fit of the model. Accept-able calibration was demonstrated by statistically analysing the relationship between predicted and observed concentra-tions for the selected parameters. A linear regression between simulated (predicted) TSI and observed TSI values is shown in Fig 3.

The model was assessed by predicting the observed versus predicted values, and this showed a performance index $\left(\mathrm{R}^{2}\right)$ of $95.1 \%$. This shows that the model is able to use different nutrients and transparency values to predict TSI values for various lagoons in Ghana. The model is able to predict lower or oligotrophic TSI values better than higher or hypereutrophic values. The model was then used to predict various TSI values for the lagoons.

Validation of the model. The closeness of the computed curves to the experimental data points gives a visual impression of the agreement, but an objective mathematical estimate of the degree of fit is more satisfactory for optimising the model. The simplest relationship would be a straight line (Hardisty et al., 1993) of the form: Observed results $=\mathrm{m}$ (Predicted results) $+\mathrm{C}$, where $\mathrm{m}=$ 
gradient (taken from the model graph) and $\mathrm{C}=$ a constant determined by any one of a number of statistical techniques. Such a plot would, therefore, show the model's predictions on the X-axis and the observations on the y-axis. Then a straight line with a slope of 1 and zero intercept indicates a validated model, and $\mathrm{R}^{2}=$ Performance index (Hardisty et al., 1993) of the validated model, also termed the coefficient of determination (Chapra, 1997). For the data set used to model TSI, $\mathrm{R}^{2}=0.9514$, which is deemed to be adequate for the present purpose. The slope $=$ 0.942 , which is also very close to 1 . The over all equation is $y=0.9417 x+2.6381$ (Fig. 3).

\section{Conclusion}

The trophic index of Benya, Nakwa, Amisa and Nyanya ranges between 35.0-39.0 and falls within Carlson's TSI range scale of 30-40, which implies that their waters are oligotrophic. The high phosphorus $(231.9 \mathrm{~kg} /$ day $)$ and nitrogen $(927.9 \mathrm{~kg} /$ day $)$ recorded at Nyanya lagoon are as a result of domestic activities mainly from the wastes generated from humans into the lagoon and its surroundings. The Oyibi lagoon is mildly eutrophic (Carlson's TSI scale of 56) in the riverine portion because of agricultural and other domestic activities. However, due to dilution and mixing at the seaward end, which is moderately clear, has TSI of 42. Similarly, Muni lagoon is moderately clear with TSI range of 35.8-43.1. The Sakumo II lagoon is hypereutrophic at the riverine end (Carlson's TSI of 87.8). The seaward end was oligotrophic. The nutrient inputs into lagoons as well as transparency are direct impacts of human activities.

The model has proved to be useful in explaining the impact of human activities on the trophic status of lagoons in Ghana. The model has also helped in explaining the four key parameters, $\mathrm{PO}_{4}-\mathrm{P}, \mathrm{NH}_{4}-\mathrm{N}, \mathrm{NO}_{3}-\mathrm{N}$ and Trans. One advantage is that, instead of measuring chlorophyll "a" to determine the TSI, one can determine routinely the four parameters to predict the trophic status of the lagoon.

\section{Acknowledgement}

The authors wish to thank the University of Rhode Island of USA and CSIR-Water Research Institute (CSIR-WRI) for the study grant for this project. They particularly acknowledge Mr S. Abu and other technical staff of CSIR-WRI for their assistance. The facilities used in both Ghana and Rhode Island are also acknowledged.

\section{References}

American Public Health Association (1998). Standard Methods for the Examination of Water and Wastewater, 14 edn. Washington, D.C., 1193 pp.

Asante K. A., Ansa-Asare O. D., Asmah R. and Biney C. A. (2003). Impact of Korle Lagoon on Immediate Inshore Waters of Accra. J. applied Sci. Technol 8(1 \& 2): 44-54.

Birch P. B., Gordon D. M. and McComb A. J. (1981). Nitrogen and phosphorus nutrition of cladophora in the PeelHarvy estuarine system, Western Australia. Bot. Mar. 34: 381-7.

Boughey A.S. (1957) Ecological studies of tropical coastlines. The Gold Coast, West Africa. J. Ecol. 45: 665-687.

Carlson R. E. (1977). A trophic state index for lakes. Limnol. Oceanogr. 22: 361-369.

Chapra C. S. (1997) Surface Water Quality Modelling. The McGraw-Hill Company, Inc. New York. pp. 381-385.

Dickson K. B. and Benneh G. (1980). A new Geography of Ghana, metricated edn. Longman Group Ltd, London.

Entsua-Mensah M., de Graft- Johnson K. A. A., Ansa-Asare, O. D., Amevenku F., Quarcoopome T. and Biney C. A. (2004). The Impact of Salt Winning on Coastal Biodiversity in Ghana. Report Prepared for the French Embassy, Accra, Ghana.

FoE (Friends of the Earth, Ghana) (1994). Wetlands Management in Ghana. A Research Project Sponsored by IDRC, Canada (Summary report)

France J. and Thornley J. H. M. (1984). Mathematical models in agriculture. Butterworths, London. p. 30.

Hardisty J., Taylor D. M. and Metcalfe S. E. (1993). Computerised environmental modelling - a practical introduction using Excel. John Wiley, New York. pp. 1-50.

West African Journal of Applied Ecology, Vol. 12, 2008 
Havens K. E. H. J., Carrick E., Lowe F. and Coveney M. (1999). Contrasting relationships between nutrients, chlorophyll a and Secchi transparency in two shallow subtropical lakes: Lakes Okeechobee and Apopka (Florida, U.S.A.). J. Lake Reserv. Mgmt 15: 298-309.

Maybeck M., Deborah V. C. and Helmer R. (1990). Global Fresh Water Quality, a First Assessment. World Health Organization/United Nations Environment Programme, Cambridge, Massachusetts, USA.

Suess M. (1982). Examination of Water for Pollution Control, vol. 1-3. Pergamon Press, Oxford. pp. 45-55.

Statisitical Service Ghana (2000). The population census of Ghana. Statitistical Service, Accra.

Wetzel R. G. (2001). Limnology, 3E. Lakes and River Eco-systems. Academic Press, San Diego, USA.

Zhuang Z. Y. (1992). Barrier lagoon system. In Modern Marine Geology, pp. 212-216. Quingdao Ocean University Press. 